\title{
Morphometric Study on the Leaf Width of the Seagrass, Halodule in Relation to Density, Exposure, Light and Temperature in the Central Visayas, Philippines
}

\author{
BILLY THEODORUS WAGEY \\ Universitas Sam Ratulangi, Manado Indonesia \\ ORCID No. 0000-0003-4350-8683 \\ billywagey2010@gmail.com
}

\begin{abstract}
The study was designed to validate the hypotheses that the leaf widths of Halodule differ between depths (intertidal and subtidal), density and light intensity in three sites in Central Philippines. The sites were Bantayan Beach, Banilad Beach, and Tubod Beach. Shoot density was determined by counting the shoots $/ 1 \mathrm{~m}^{2}$ quadrat; the ImageJ software was applied to measure the leaf width of the samples; Hobo pendant data loggers (model UA-002-08) were used to measure light intensity and temperature.
\end{abstract}

Keywords: Seagrass, Morphometric, leaf width, Halodule

\section{INTRODUCTION}

The marine angiosperm, Halodule uninervis is one of the dominant tropical seagrass species distributed from Persian Gulf to Northwest Australia (den Hartog 1970; Phillips and Meñez 1988; Green and Short 2003). It encompasses a wide range of habitats, from the muddy intertidal to the reef, and is tolerant of large fluctuations in salinity. This species plays an important role as a primary producer, as habitat for fauna and aids in the protection of coastal areas through stabilization of the substrate with its dense rhizosphere. 
In the Philippines, an archipelagic country with 7,100 islands, seven seagrass genera are considered as representative of tropical seas (Phillips and Meñez 1988). A total of 12 species (Halodule uninervis (Forsskål) Ascherson, Halodule pinifolia (Miki) den Hartog, Thalassodendron ciliatum (Forsskål) den Hartog, Cymodocea rotundata Ehrenberg and Hemprich, ex Aschers, Cymodocea serrulata (R. Brown) Aschers and Magnus, Syringodium isoetifolium (Aschers) Dandy, Halophila ovalis (R. Brown) Hooker f., Halophila spinulosa (R. Brown) Aschers, Halophila decipiens Ostenfeld, Halophila minor (Zollinger) den Hartog, Thalassia hemprichii (Ehrenberg) Aschers and Enhalus acoroides (L.f) Royle) have been recorded (Meñez et al.1983; Meñez and Calumpong 1983; 1985).

Halodule uninervis and $H$. pinifolia can grow together or can occur in separate patches. In addition, $H$. uninervis have two varieties: the narrow-leaved and the wide-leaved. The identification of these species is mainly based on the morphology of leaf blade widths and the shape of leaf tips. For $H$. pinifolia, the leaf blades are linear, $4-15 \mathrm{~cm}$ long, not more than $1.5 \mathrm{~mm}$ wide. Leaf tips are obtuse with few irregular serrations. Leaf margin is entire; conspicuous mid-rib furcate at the tip. On the contrary, $H$. uninervis leaf blades are linear and narrow at the base, $2-5 \mathrm{~mm}$ wide and may reach up to $15 \mathrm{~cm}$ in length. Leaf tips are tridentate. Leaf margin is entire (Meñez et al. 1983). However, this identification of leaf morphology is still being argued by several authors (den Hartog 1970; Johnstone 1978; McMillan 1983; Fortes 1986; Lewmanomont et al.1996; Sidik et al. 1999; Kuo and den Hartog 2001, Waycott et al. 2004, den Hartog and Kuo 2006; Sidik et al. 2008). The summary of observations on the leaf morphology is described by Hedge et al. (2009) (see Table 1).

Regardless of the historical use of floral morphology as the basis of division of species of vascular plants, leaf characters have been used to identify species of Halodule because of the uncommonness of flower production. To date, three leaf characters have been used: width, presence or absence of lacuna around the midvein, and morphology of the mature tip (mostly either bidentate or tridentate) (Sauvageau 1891; Phillips 1967, den Hartog 1970, and den Hartog and Kuo 2006). 
Table 1. Summary of observations on the leaf morphology of the Halodule uninervis complex (modified after Hedge et al., 2009)

\begin{tabular}{|l|l|l|}
\hline Author/ Year & Narrow Leaf Type & Wide Leaf Type \\
\hline $\begin{array}{l}\text { Den Hartog, } 1970 \\
\text { (Indo-Pacific) }\end{array}$ & $\begin{array}{l}<1.0 \text { mm: Prefers exposed } \\
\text { sandy shores exhibiting } \\
\text { unsuitable salinity }\end{array}$ & $\begin{array}{l}\text { 1.0-3.5 mm: Prefers sheltered } \\
\text { muddy habitats which suggests } \\
\text { a response to nutrient/salinity/ } \\
\text { light flux }\end{array}$ \\
\hline $\begin{array}{l}\text { Johnstone, 1978 (Papua } \\
\text { New Guinea) }\end{array}$ & $\begin{array}{l}\text { High intertidal zone, often } \\
\text { pure stands, well above upper } \\
\text { limit for other seagrasses } \\
\text { (ability to resist desiccation and } \\
\text { salinity flux), prefers compact } \\
\text { sand. }\end{array}$ & $\begin{array}{l}\text { 0.5 m below mean low water } \\
\text { to } 5 \text { m subtidal, found in } \\
\text { community with other species, } \\
\text { prefers coarse coral substrate. }\end{array}$ \\
\hline $\begin{array}{l}\text { McMillan, 1983 (Shark } \\
\text { Bay, WA) Suggests depth } \\
\text { profile for complex }\end{array}$ & $\begin{array}{l}\text { Prefers firm silty substrates, } \\
\text { exposed during spring low tide. } \\
\text { Size range }<1.8 \text { mm. Found } \\
\text { with small leaved H. ovalis. }\end{array}$ & $\begin{array}{l}\text { Prefers muddy areas, mangrove } \\
\text { fringes, lower intertidal zone, } \\
\text { not exposed during spring low } \\
\text { tides. Size range }>1.8 \text { mm. }\end{array}$ \\
\hline $\begin{array}{l}\text { Lewmanomont et al., } \\
\text { 1996 }\end{array}$ & $\begin{array}{l}\text { Approximately 1-2 mm. } \\
\text { Intertidal and subtidal }\end{array}$ & $\begin{array}{l}\text { 2.1-3.8 mm. Intertidal and } \\
\text { subtidal, but mostly found at } \\
\text { greater depths. }\end{array}$ \\
\hline $\begin{array}{l}\text { Sidik et al., 1999 } \\
\text { (Malaysia) }\end{array}$ & $\begin{array}{l}\text { Size range 0.5-1.5 mm. Lower } \\
\text { intertidal to subtidal, sandy/ } \\
\text { muddy and sandy/coral rubble } \\
\text { substrate. }\end{array}$ & $\begin{array}{l}\text { Size range 1.5-4.0 mm. } \\
\text { Subtidal zone, sandy/muddy } \\
\text { to muddy areas and mangrove } \\
\text { fringes. }\end{array}$ \\
\hline
\end{tabular}

A number of environmental conditions have been identified critical to seagrass survival. Light intensity, in connection with water depth, has long been considered the primary factor controlling seagrass distribution and biomass. Altered seagrass depth distribution could be affected by water quality, which also affects light penetration (Dawson and Dennison 1996). The depth limit of seagrass meadows is governed by the photosynthetic active radiation (PAR). Seagrasses grow to a maximum depth where PAR is sufficient enough for metabolism. The relationship between maximum depth limit of seagrasses and light penetration has been recognized. While the minimum light requirements for seagrasses vary from 4-29\% among and within species values are consistent for many species (Short and Coles 2001).

Earlier studies also demonstrated that temperature (McMillan 1979; McMillan et al. 1982; Silberhorn et al. 1983; Pirc 1986; and Zakaria et al. 
1999), light (McMillan 1980a; Beer and Waisel 1982; Pirc 1986; Herbert 1986; Dennison 1987; Vermaat et al. 1997, Ralph 1999; and Longstaff and Dennison 1999), salinity (McMillan 1980b; McMillan et al. 1982; Phillips et al. 1983; and Hellblom and Björk 1999), nutrients (McMillan 1980c; van Tussenbroek 1994; and Sidik et al. 1999), and water depth (Keller and Harris 1966; Jacobs and Pierson 1981; Phillips and Backman 1983; Durako and Moffler 1985; Lopez and Obando 1999) affect seagrass morphology (e.g. leaf length) and regulate some of their physiological activities including biomass production, photosynthesis, and reproduction.

Although many studies have investigated how light and temperature affect seagrasses, little work has been done in this topics in the Philippines. This study proposed to investigate the morphology variations and characteristics of the genus Halodule in Central Visayas. This study will also attempt to provide explanations to these differences.

\section{MATERIALS AND METHODS}

\section{Study Site}

The study sites were located in Bantayan Beach $\left(9^{\circ} 19^{\prime} 53.26^{\prime \prime} \mathrm{N}\right.$ and $\left.123^{\circ} 18^{\prime} 36.26^{\prime \prime} \mathrm{E}\right)$ and Banilad Beach (9 $9^{\circ} 16^{\prime} 35.49^{\prime \prime} \mathrm{N}$ and $\left.123^{\circ} 18^{\prime} 15.45^{\prime \prime} \mathrm{E}\right)$ in Dumaguete City Negros Oriental, and Tubod, Siquijor Island (9 ${ }^{\circ} 13^{\prime} 20.58^{\prime \prime} \mathrm{N}$ and $123^{\circ} 30^{\prime} 58.70$ ”E), Central Visayas, Philippines (Plate 1). Sites were established at two different exposures and densities; Intertidal (with low and high Halodule uninervis/pinifolia cover) and subtidal (with low and high Halodule uninervis/ pinifolia cover). The percent cover was estimated by visual observation (Table 2).

Table 2. Determination of percent cover

\begin{tabular}{|c|c|c|c|c|c|}
\hline \multicolumn{2}{|c|}{ Site } & Species & $\begin{array}{c}\text { Cover in } \\
\%\end{array}$ & $\begin{array}{c}\text { Category } \\
\text { based on } \\
\text { Tomasko et } \\
\text { al. 1993 (\%) }\end{array}$ & $\begin{array}{c}\text { Category } \\
\text { used in this } \\
\text { study }\end{array}$ \\
\hline \multirow{3}{*}{ BANTAYAN } & \multirow{3}{*}{ Intertidal } & H.uninervis & $10-20$ & $<50$ & Low \\
\cline { 3 - 6 } & & H.pinifolia & $10-30$ & $<50$ & Low \\
\cline { 3 - 6 } & \multirow{2}{*}{ Subtidal } & H.pinifolia & $50-65$ & $>50$ & High \\
\cline { 3 - 6 } & & H.uninervis & $10-35$ & $<50$ & Low \\
\cline { 3 - 6 } & H.uninervis & $50-60$ & $<50$ & High \\
\hline
\end{tabular}




\begin{tabular}{|l|l|l|l|l|l|}
\hline \multirow{4}{*}{ BANILAD } & \multirow{3}{*}{ Intertidal } & H.pinifolia & $15-40$ & $<50$ & Low \\
\cline { 3 - 6 } & \multirow{3}{*}{ Subtidal } & H.pinifolia & $55-80$ & $>50$ & High \\
\cline { 3 - 6 } & & H.uninervis & $10-35$ & $<50$ & Low \\
\cline { 3 - 6 } & \multirow{3}{*}{ SIQUIJOR } & H.uninervis & $55-75$ & $>50$ & High \\
\hline \multirow{3}{*}{ Intertidal } & & H.uninervis & $10-15$ & $<50$ & Low \\
\cline { 3 - 6 } & & H.pinifolia & $15-40$ & $>50$ & Low \\
\cline { 3 - 6 } & \multirow{3}{*}{ Subtidal } & H.pinifolia & $55-85$ & $>50$ & High \\
\cline { 3 - 6 } & & H.uninervis & $10-25$ & $<50$ & Low \\
\cline { 3 - 6 } & & H.uninervis & $50-75$ & $>50$ & High \\
\hline
\end{tabular}

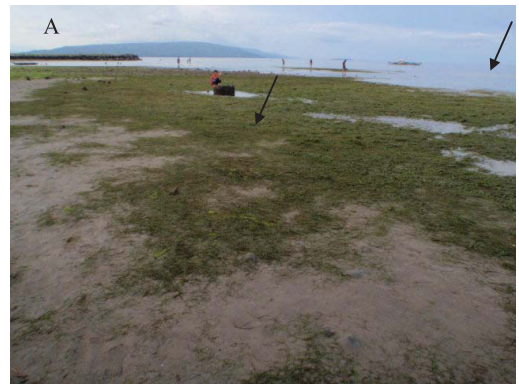

B
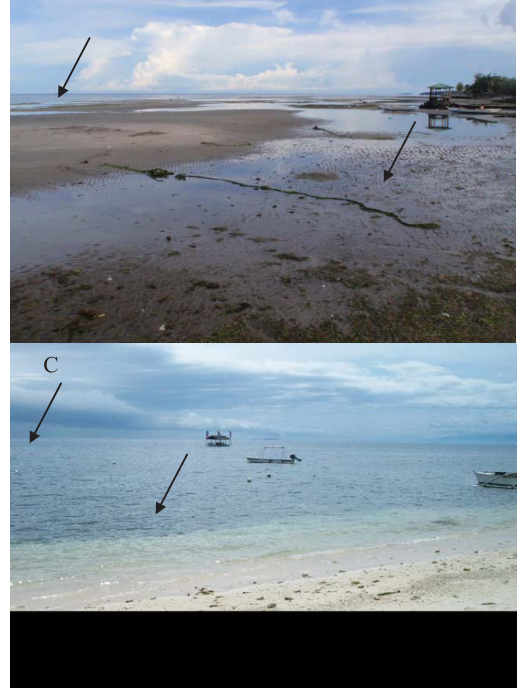

Plate 1. The study sites: A. Bantayan Beach and B. Banilad Beach in Negros Oriental, and C. Tubod Beach, Siquijor. 


\section{Density Measurements}

Sampling was conducted using $1 \mathrm{~m}^{2}$ quadrats, subdivided into $25 \mathrm{X} 25$ $\mathrm{cm}$ subquadrats, which were laid randomly at each station in the three sites ten quadrats where taken at each sample site. Percentage cover of each species was determined by counting the number of subquadrats occupied. This was categorized into: 0 percent cover (when frequency was 0 ), $<10$ percent cover, $10-50$ percent cover, and $>50$ percent cover (Tomasko et al. 1993; Short and Coles 2001). Low Halodule density was described as below 50\% cover, whereas the high Halodule density was described as above 50\% cover. Shoot density was determined by counting the shoots of Halodule inside one subquadrat. Shoot density was obtained by multiplying the number of shoots taken from 1/16th of the quadrat by the frequency to estimate the total density of the species in the 1 $\mathrm{m} \times 1 \mathrm{~m}$ plot.

In this study, the shoot density was broadly classified into two: low where the shoot density was lower than 500 shoots $\mathrm{m}^{-2}$ and high where the shoot density was higher than 500 shoots $\mathrm{m}^{-2}$.

\section{Leaf Measurements and Analysis}

A total of fifty samples $(n=50)$ of each species from the intertidal (with low $H$. uninervis/pinifolia density), intertidal (with high $H$. uninervis/pinifolia density), subtidal (with low $H$. uninervis/pinifolia density) and subtidal (with high $H$. uninervis/pinifolia density) were randomly collected from all the quadrats for measurements. Samples collected, were rinsed free of sediment using seawater, then placed in labeled net bags. They were brought to IEMS Laboratory and kept in an outdoor tank for subsequent processing and analysis at the Botany lab.

Shoots were carefully cleaned in filtered seawater, and epiphytes attached to the leaves were removed by gently scraping them with the hand. After cleaning, image documentation of the samples was conducted using an underwater Olympus digital camera $(\boldsymbol{\mu} 1030 \mathrm{SW})$. The camera was set at $50 \mathrm{~cm}$ distance. A ruler was placed beside the sample to use as the standard distance measurement. All photos were stored and saved in .jpg files according to its species name, site, tidal area or station and density, and the date of collection.

The ImageJ $1.42 \mathrm{u}$; java1.6; 32 bit, a public domain open source software, was applied to measure the leaf width of the samples (Rasband 2011). The photo of the seagrass sample (in JPEG image) was placed on the desktop of the screen under the ImageJ toolbar program. With a mouse, a $5 \mathrm{~cm}$ was precisely drawn within the ruler in the photo by enlarging the photo with the magnifying button. 
Scale was set up by pressing the Analyze text tool. In the dialog box of the set scale, " 50 " point were typed at the known distance box (50 represented the 5 $\mathrm{cm}$ of line dragged). Then, in the Unit of Length box " $\mathrm{mm}$ " was typed in. Under Analyze text tool, Set Measurement was set up to 4 digits decimals (since ImageJ can measure from 0-9 decimal places). The photo was enlarged to focus in on the sample area, and then a line was drawn from one edge to the other edge. Under the Analyze tool bar, the result was obtained by pressing the "measure" text tool or by simply press "Control M" on the keyboard. Measurements were taken at the bottom, middle and upper parts of each leaf and were averaged. For uniformity, the measurements were taken only from the second leaf of the second shoot for each sample.

\section{Temperature and Light Measurements}

Hobo pendant data loggers (model UA-002-08) were used to measure light intensity and temperature (Plate 2). A pendant logger was deployed in each of the intertidal and subtidal zones for about a month at the time the seagrasses were collected. The loggers were programmed to store data of temperature and light intensity every ten minutes and were set up with actual date and time when installed. Each logger was covered with plastic tape and tied to an iron bar. The iron bars were stuck into the seafloor within the seagrass bed with the tip of the loggers facing the equator. This allowed each data logger to receive the maximum light intensity. The loggers were inspected every four days for any damage and proper placement, and were cleaned from all marine growths. Every two weeks, the loggers were taken out to upload the data. The data were exported and tabulated into Microsoft Excel 2007 program to get the mean of light intensity and temperature per day per month and per year.

Sampling and measurements were conducted during the northeast monsoon (March-May 2010) and the southwest monsoon (October-December 2010).

Generated data were summarized using descriptive statistics such as mean and standard deviation.

Statistical analysis using SPSS (Ver.14.0) was conducted in an effort to identify trends, or variances in the data. A t-test analysis was used to assess whether the mean leaf width of two groups at different densities and light exposure are statistically different. One-Way ANOVA was used to determine significant differences of leaf width among the sites. The Tukey's Test was used to determine where the difference lies. 


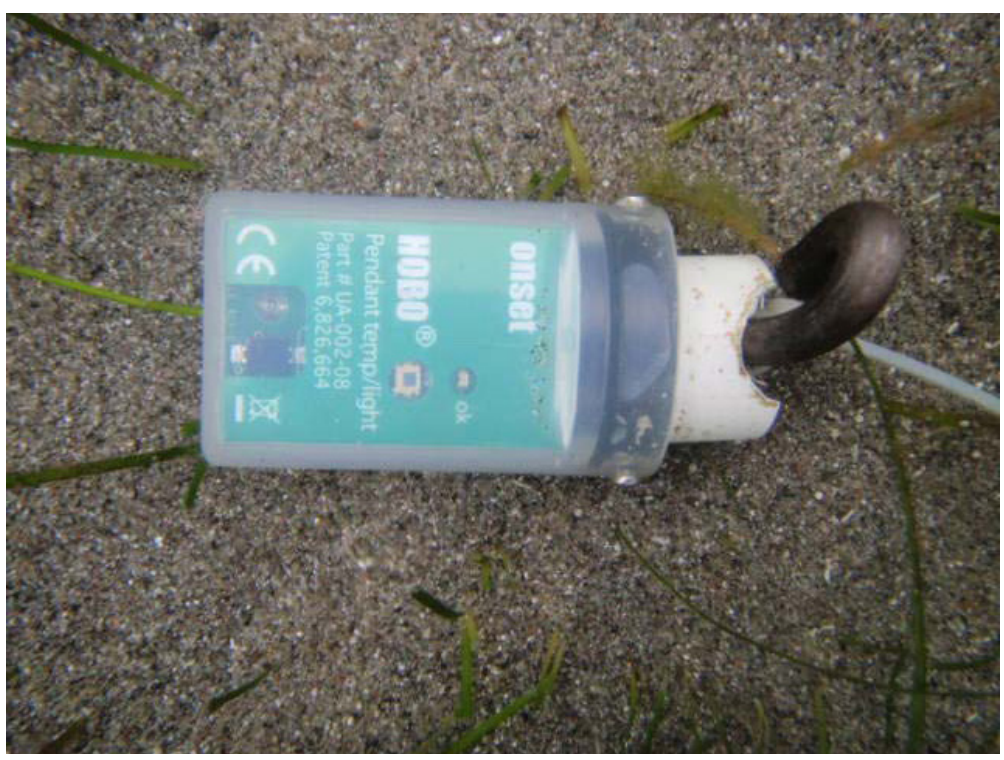

Plate 2. Hobo pendant logger deployed in seagrass bed of Halodule pinifolia in Bantayan beach.

\section{RESULTS AND DISCUSION}

\section{Shoot Density}

Halodule uninervis occupied the intertidal and subtidal areas in Bantayan Beach, Banilad Beach and Siquijor Beach. However, in the intertidal zone of Bantayan and Siquijor, this species was only found at low density. On the contrary, H.pinifolia was only found in the intertidal zone of the three sites but at low and high densities.

The mean shoot density of $H$. uninervis in all collection sites ranged from $180.80 \pm 39.95$ shoot $\mathrm{m}^{2}$ to $968.00 \pm 71.26$ shoot $\mathrm{m}^{2}$, whereas the mean shoot density of $H$. pinifolia ranged from $254.40 \pm 66.81$ shoot $\mathrm{m}^{2}$ to $998.40 \pm 82.35$ shoot $\mathrm{m}^{2}$ (Table 3). Result of this study shows that shoot density of $H$. uninervis varied among sites. 
Table 3. Mean shoot density (no. of shoots $\mathrm{m}^{-2}$ ) of Halodule uninervis and $H$. pinifolia in three sites $(\mathrm{N}=10)$. SD represents standard deviation

\begin{tabular}{|c|c|c|c|c|}
\hline \multicolumn{2}{|c|}{ Site } & Density & Halodule uninervis & Halodule pinifolia \\
\hline \multirow{4}{*}{ BANTAYAN } & \multirow{2}{*}{ Intertidal } & Low & $180.80 \pm 39.95$ & $254.40 \pm 66.81$ \\
\hline & & High & NA & $892.80 \pm 76.10$ \\
\hline & \multirow{2}{*}{ Subtidal } & Low & $227.20 \pm 61.18$ & NA \\
\hline & & High & $920.00 \pm 88.04$ & NA \\
\hline \multirow{4}{*}{ BANILAD } & \multirow{2}{*}{ Intertidal } & Low & NA & $313.60 \pm 58.52 *$ \\
\hline & & High & NA & $998.40 \pm 82.35 *$ \\
\hline & \multirow{2}{*}{ Subtidal } & Low & $296.00 \pm 64.11$ & NA \\
\hline & & High & $912.00 \pm 79.46$ & NA \\
\hline \multirow{4}{*}{ SIQUIJOR } & \multirow{2}{*}{ Intertidal } & Low & $195.20 \pm 47.58$ & $270.40 \pm 59.13$ \\
\hline & & High & NA & $745.60 \pm 90.57$ \\
\hline & \multirow{2}{*}{ Subtidal } & Low & $206.40 \pm 56.67$ & NA \\
\hline & & High & $968.00 \pm 71.26$ & NA \\
\hline
\end{tabular}

$N A=$ Not Aplicable

Between the intertidal areas in Bantayan and Siquijor with low density, mean shoot densities of $H$. uninervis did not vary much, showing no significant difference (T-Test: $\mathrm{F}=0.150 ; p=0.703$ ). But for the subtidal areas with low density, one-way ANOVA revealed a significant difference $(\mathrm{F}=5.96 ; p=0.007)$ among the three sites with the highest mean shoot density in Banilad (Figure 1). This is further revealed by Tukey's test. Shoot densities in the subtidal area with high density bed, however, were not significantly different among sites $(\mathrm{F}=1.98$; $p=1.58)$ (Figure 2).

For $H$. pinifolia, although the mean shoot densities in the intertidal areas appeared to be higher in Banilad than in Siquijor and Bantayan (Table 3 and Figures 3 and 4), one-way ANOVA showed no significant difference in the low density beds among sites $(\mathrm{F}=2.943 ; p=.07)$. In contrast, shoot densities in the high density beds were significantly different $(\mathrm{F}=23.313 ; p=0.000)$. 


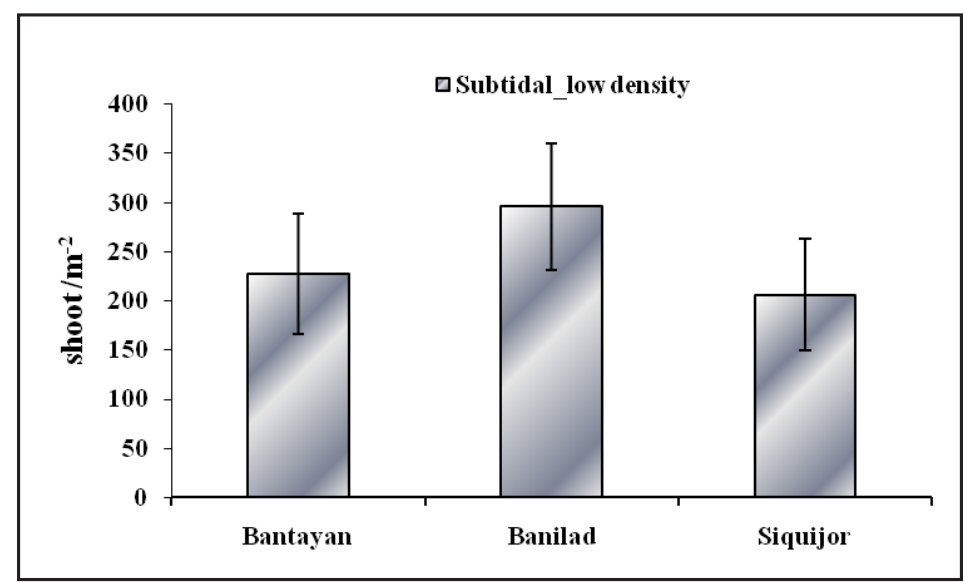

Figure 1. Mean shoot density (no. of shoots $\mathrm{m}^{-2}$ ) of $H$. uninervis in the subtidal area low density bed in three sites $(\mathrm{N}=10)$. Error bars indicate \pm standard deviation.

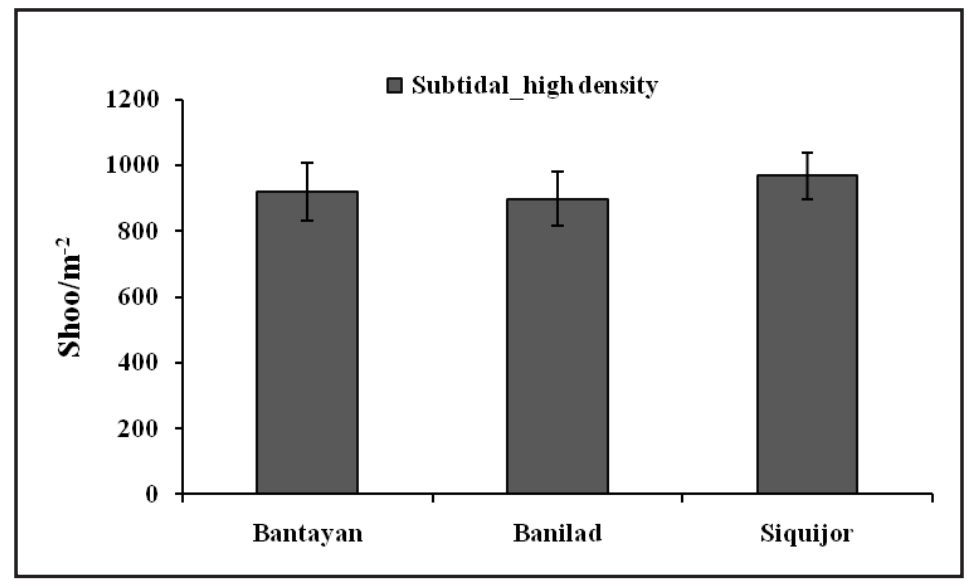

Figure 2. Mean shoot density (no. of shoots m-2)

of Halodule uninervis in subtidal zone at high density bed in three sites $(\mathrm{N}=10)$. Error bars indicate \pm standard deviation. 


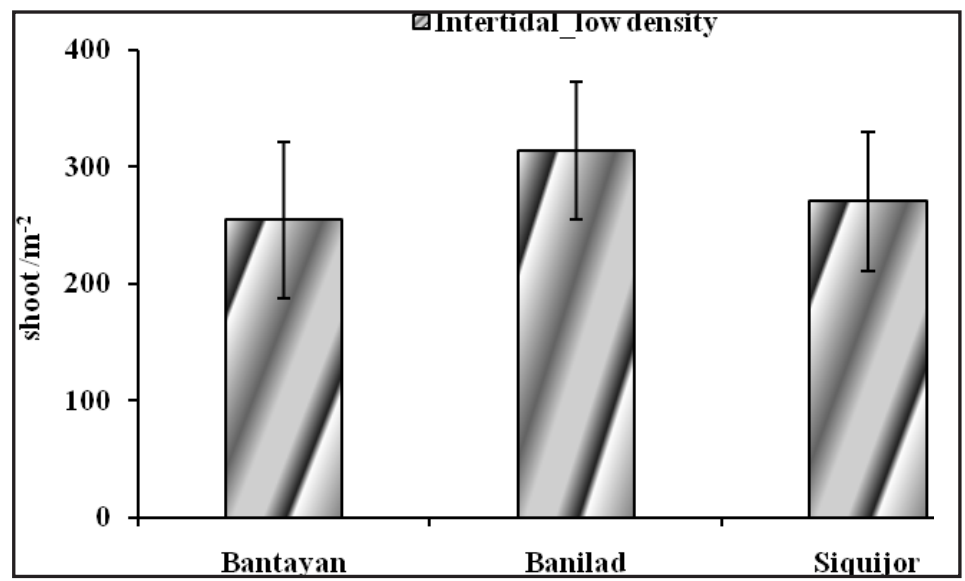

Figure 3. Mean shoot density (no. of shoots $\mathrm{m}^{-2}$ ) of $H$. pinifolia in the intertidal area at low density bed in three sites $(\mathrm{N}=10)$. Error bars indicate \pm standard deviation.

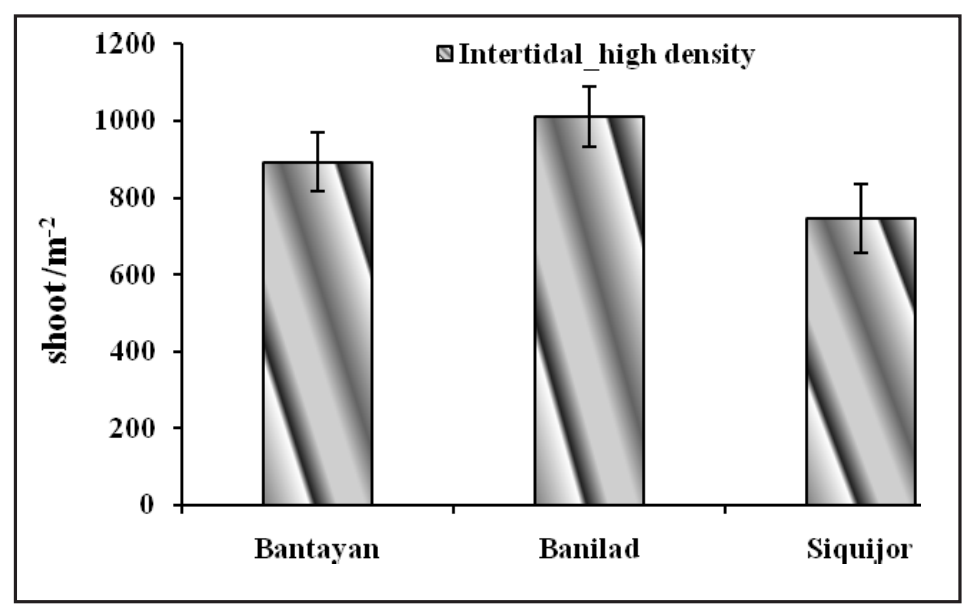

Figure 4. Mean shoot density (no. of shoots $\mathrm{m}^{-2}$ ) of $H$. pinifolia in the intertidal area at high density bed in three sites $(\mathrm{N}=10)$. Error bars indicate \pm standard deviation. 


\section{Leaf Width}

The leaf width of $H$. uninervis in all sites ranged from 2.7 to $4.0 \mathrm{~mm}$, whereas the leaf width of $H$. pinifolia ranged from 0.8 to $1.8 \mathrm{~mm}$ (Table 4 and Table 5). The tables below summarize the mean leaf widths based on the tidal station and densities in the observation sites.

Table 4. Computed mean leaf width $(\mathrm{mm})$ of Halodule uninervis in three sites $(\mathrm{N}=50)$. SD represents standard deviation

\begin{tabular}{|c|c|c|c|c|}
\hline \multirow{2}{*}{\multicolumn{2}{|c|}{ Site }} & \multirow{3}{*}{$\begin{array}{c}\text { Density } \\
\text { Low }\end{array}$} & \multicolumn{2}{|c|}{ Leaf Width (mm) } \\
\hline & & & \multirow{2}{*}{$\frac{(\text { mean } \pm \text { SD })}{3.1 \pm 0.2}$} & \multirow{2}{*}{$\begin{array}{c}\text { range } \\
2.7-3.5\end{array}$} \\
\hline \multirow{3}{*}{ BANTAYAN } & Intertidal & & & \\
\hline & \multirow{2}{*}{ Subtidal } & Low & $3.3 \pm 0.3$ & $2.8-3.9$ \\
\hline & & High & $3.4 \pm 0.2$ & $2.8-3.9$ \\
\hline \multirow[b]{2}{*}{ BANILAD } & \multirow{2}{*}{ Subtidal } & Low & $3.4 \pm 0.2$ & $3.0-3.8$ \\
\hline & & High & $3.5 \pm 0.3$ & $3.0-4.0$ \\
\hline \multirow{3}{*}{ SIQUIJOR } & Intertidal & Low & $3.1 \pm 0.2$ & $2.8-3.8$ \\
\hline & \multirow{2}{*}{ Subtidal } & Low & $3.2 \pm 0.3$ & $2.9-3.9$ \\
\hline & & High & $3.3 \pm 0.3$ & $3.0-4.0$ \\
\hline
\end{tabular}

Table 5. Computed mean leaf width $(\mathrm{mm})$ of Halodule pinifolia in three sites $(\mathrm{N}=50)$. SD represents standard deviation

\begin{tabular}{|c|c|c|c|c|}
\hline \multicolumn{2}{|c|}{ Site } & \multirow{2}{*}{ Density } & \multicolumn{2}{c|}{ Leaf width (mm) } \\
\cline { 3 - 5 } & & (mean \pm SD) & (mean \pm SD) \\
\hline \multirow{2}{*}{ BANTAYAN } & \multirow{2}{*}{ Intertidal } & Low & $1.2 \pm 0.2$ & $0.9-1.6$ \\
\cline { 3 - 5 } & & High & $1.3 \pm 0.2$ & $1.0-1.7$ \\
\hline \multirow{2}{*}{ BANILAD } & \multirow{2}{*}{ Intertidal } & Low & $1.4 \pm 0.1$ & $1.1-1.7$ \\
\cline { 3 - 5 } & & High & $1.4 \pm 0.2$ & $1.0-1.8$ \\
\hline \multirow{2}{*}{ SIQUIJOR } & \multirow{2}{*}{ Intertidal } & Low & $1.5 \pm 0.2$ & $1.0-1.7$ \\
\cline { 3 - 5 } & & High & $1.3 \pm 0.2$ & $0.8-1.7$ \\
\hline
\end{tabular}

In this current study, it was found out that all t-test showed significant difference both between site and exposure. T-test result showed that mean leaf 
widths were significantly different between Bantayan intertidal area low density and Siquijor intertidal area low density bed $(\mathrm{t}=-2.143 ; p=0.035)$. T-test showed also that mean leaf widths were not significantly different between Bantayan intertidal and subtidal area low density bed $(\mathrm{t}=-5.525 ; p=0.000)$. Furthermore, the mean leaf widths were significantly different between Bantayan intertidal low density bed and Banilad subtidal low density bed $(\mathrm{t}=-6.644 ; p=0.000)$. Likewise, the mean leaf widths were significantly different between Bantayan intertidal low density bed Siquijor subtidal low density bed ( $\mathrm{t}=-3.245 ; p=0.002)$.

For the subtidal area, mean leaf widths of $H$. uninervis were significantly wider in Banilad at low and high density beds (One-way ANOVA: $\mathrm{F}=6.328 ; p$ $=0.02$ and $\mathrm{F}=8.419 ; p=0.000$, respectively) (Figure 5 and Figure 6). Values for the low density beds were similar between Bantayan and Siquijor.

For $H$. pinifolia, the mean leaf widths in Banilad and Siquijor appeared to be similar but were significantly wider than those of Bantayan $(\mathrm{F}=15.469, p=$ 0.000 ) in the intertidal low density beds (Figure 7).

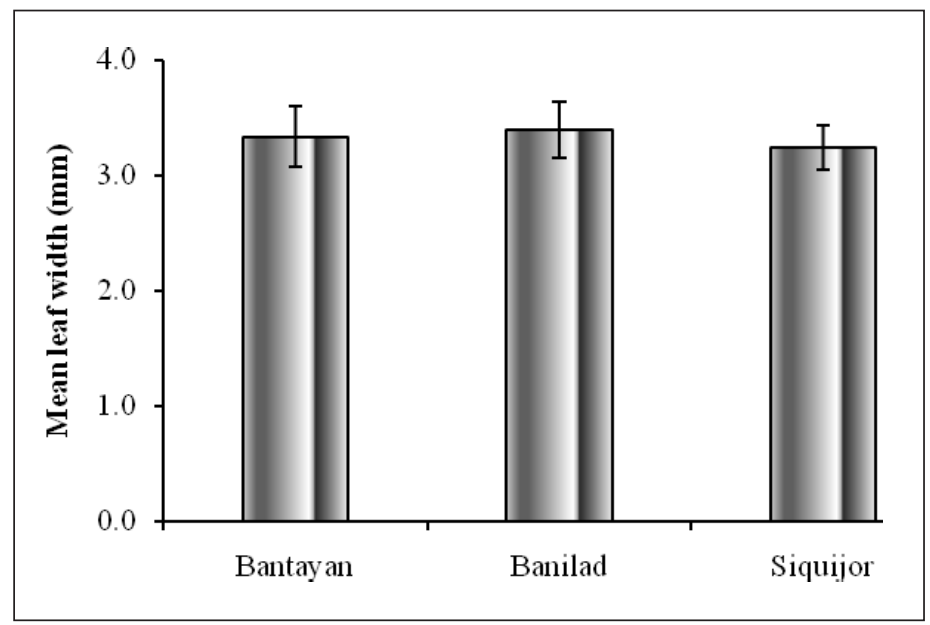

Figure 5. Mean leaf width $(\mathrm{mm})$ of $H$. uninervis in the subtidal area low density in three sites $(\mathrm{N}=50)$. Error bars indicate \pm standard deviation. 


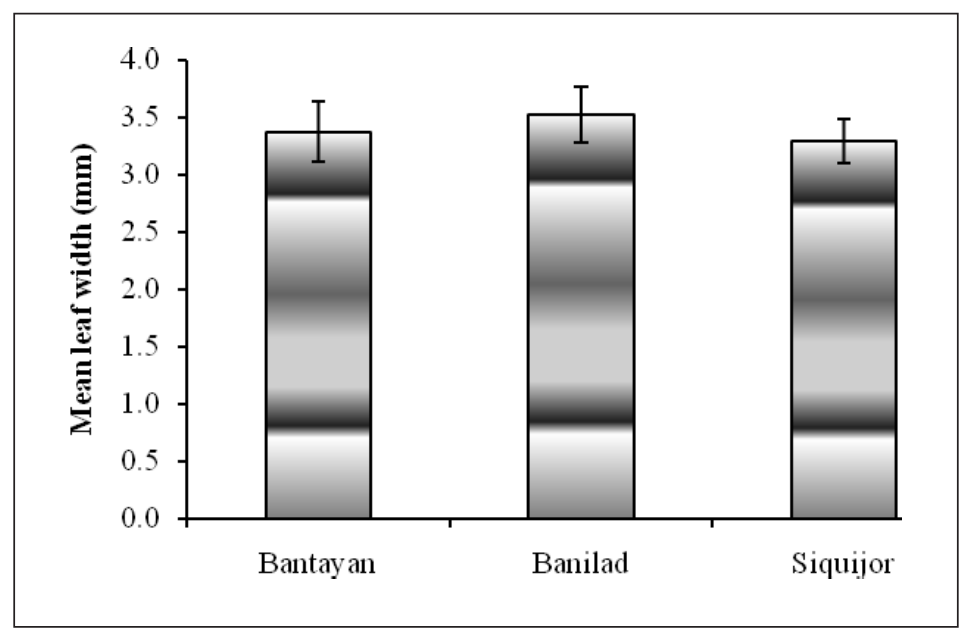

Figure 6. Mean leaf width $(\mathrm{mm})$ of Halodule uninervis in subtidal area high density bed in three sites $(\mathrm{N}=50)$. Error bars indicate \pm standard deviation.

For $H$. pinifolia, the mean leaf widths in Banilad and Siquijor appeared to be similar but were significantly wider than those of Bantayan $(\mathrm{F}=15.469, \mathrm{p}=$ 0.000) in the intertidal low density beds (Figure 7).

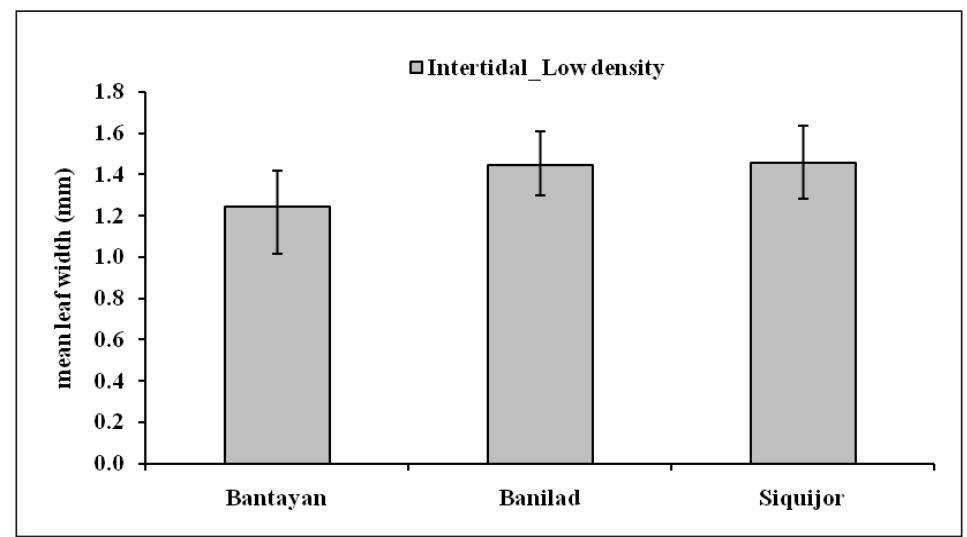

Figure 7. Mean leaf width $(\mathrm{mm})$ of $H$. pinifolia in the intertidal area at low density beds in three sites $(\mathrm{N}=50)$. Error bars indicate \pm standard deviation. 


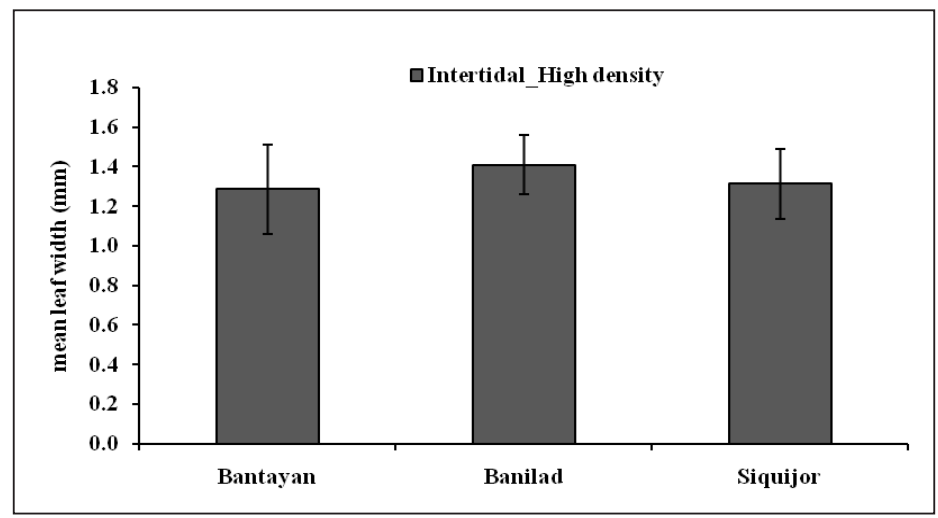

Figure 8. Mean leaf width $(\mathrm{mm})$ of $H$. pinifolia in the intertidal area at high density beds in three sites $(\mathrm{N}=50)$. Error bars indicate \pm standard deviation.

The result of ANOVA performed on mean leaf width $(\mathrm{mm})$ comparison of Halodule pinifolia in the intertidal area of high density bed showed highly significant difference $(\mathrm{F}=23.463, p=0.000)$ among the sites. Furthermore, posthoc analysis (Tukey's test) showed that the leaf width of $H$. pinifolia in the Banilad and Bantayan intertidal area with high density bed were higher than those in Siquijor. While the mean leaf width of $H$. pinifolia in Banilad and Bantayan intertidal areas with high density bed were not significantly different (Figure 8).

\section{Temperature}

The temperature in Bantayan intertidal area differed with time and month. It ranged from $28.85^{\circ} \mathrm{C}$ to $32.35{ }^{\circ} \mathrm{C}$ in both intertidal and subtidal areas. Temperature peaked at $32.35 \pm 1.28^{\circ} \mathrm{C}$ on May 2010 and $31.55 \pm 1.27^{\circ} \mathrm{C}$ on November 2001 from 13.00-13.50 hours. Whereas, in the subtidal area, the temperature peaked at $30.18 \pm 0.60^{\circ} \mathrm{C}$ and $28.64 \pm 0.95^{\circ} \mathrm{C}$ from $13.00-13.50$ hours (Figure 9 and Figure 10).

\section{Light}

The light intensity in Bantayan intertidal area also differed with time and month. Light intensity peaked at $44000.08 \pm 19163.16$ Lux on May 2010 and $36082.35 \pm 14421.41$ Lux on November 2010 from 12.00-12.50 hours. However, mean light intensity in the subtidal area did not vary during the months. At 12.00-12.50 hours, it ranged from 19163.16 6133.0 Lux on May 
2010 to $20044.60 \pm 7430.80$ Lux on November 2010 at $11.00-11.50$ hours (Figure 11 and Figure 12).

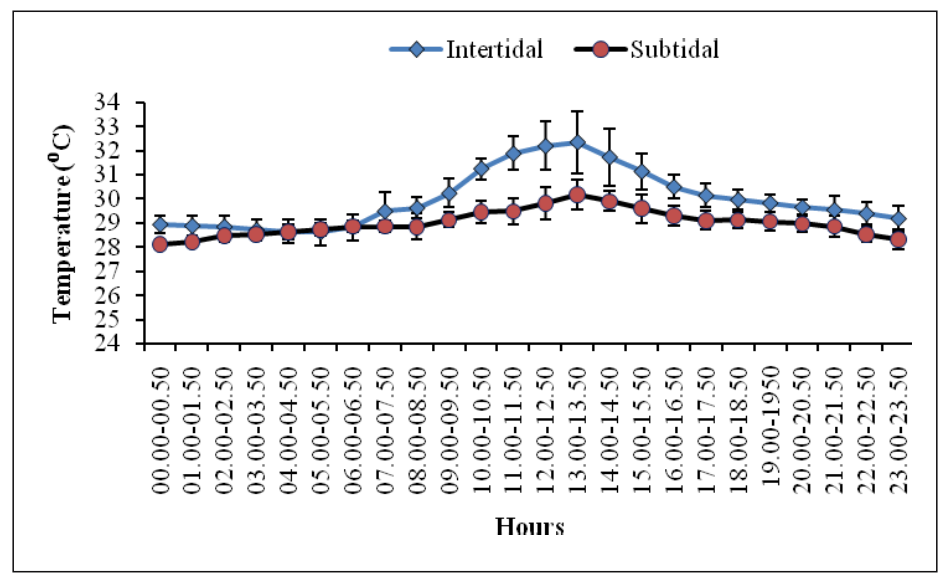

Figure 9. Mean Temperature reading on May 2010 in Bantayan intertidal and subtidal areas $(\mathrm{N}=6)$. Error bars indicate \pm standard deviation

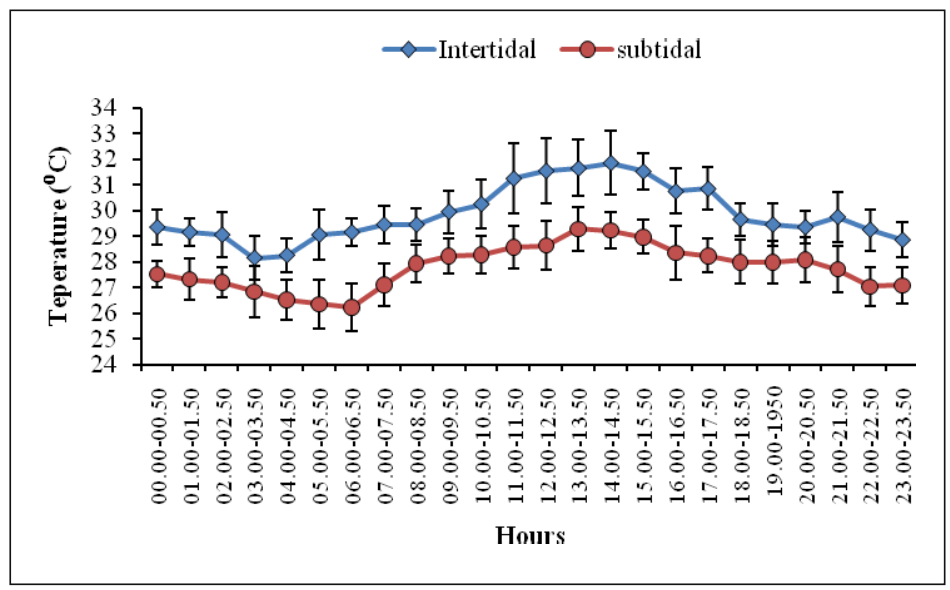

Figure 10. Mean Temperature reading on November 2010 in Bantayan intertidal and subtidal areas $(\mathrm{N}=6)$. Error bars indicate \pm standard deviation 


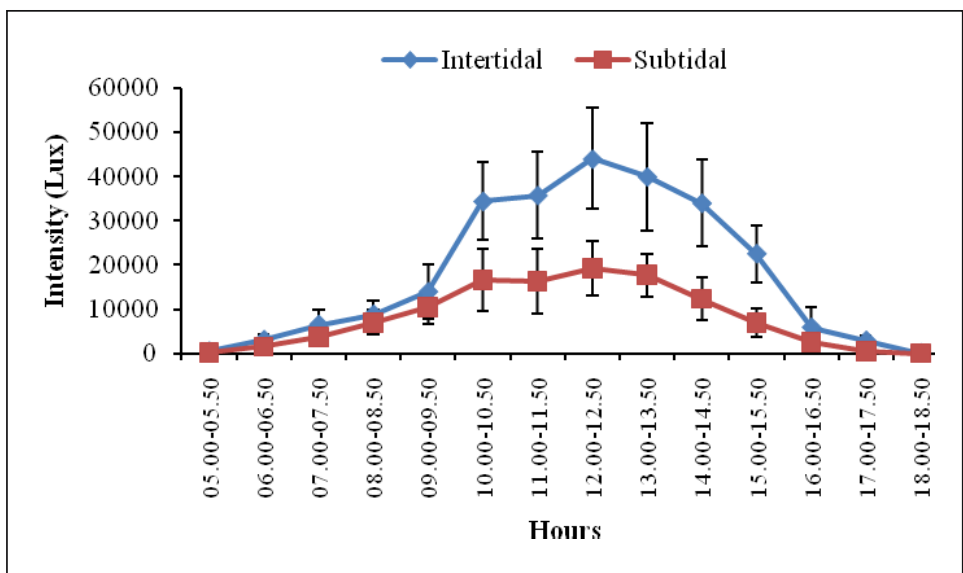

Figure 11. Mean Light intensity reading on May 2010 in Bantayan intertidal and subtidal areas $(\mathrm{N}=6)$. Error bars indicate \pm standard deviation

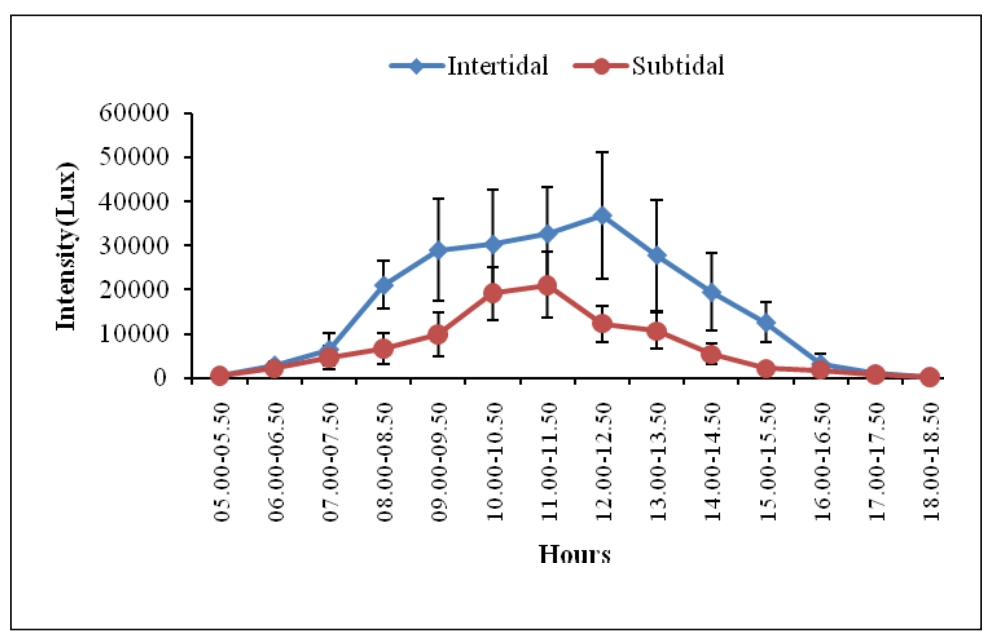

Figure 12. Mean Light intensity reading on November 2010 in Bantayan intertidal and subtidal areas $(\mathrm{N}=6)$. Error bars indicate \pm standard deviation 
The current study documented the variability of the leaf width of Halodule uninervis and Halodule pinifolia in three sites in Central Visayas. Examination of all data across the sites indicated that the leaf widths of both $H$. uninervis and $H$. pinifolia as much wider in specimen from Banilad site compare to those collected the Siquijor and Bantayan sites. In this study the mean leaf width of H. uninervis was found to vary highly between intertidal and subtidal areas, with larger leaf width observed in subtidal area. Leaf width of $H$. pinifolia on the other hand tended to be much larger in Banilad than those in Bantayan and Siquijor. However, there was no clear relationship found between the shoot density and the leaf width as well as leaf width and light intensity and leaf width and temperature. Though it was found that there was a significant difference in of leaf width among sites, it could not be ascertained as to why this is so. It is believed that this maybe a result of an interplay of all factors plus nutrients in the water column as well as in the sediment, and wave energy.

Based on the leaf width variation, $H$. uninervis was found in the range of 2-4 $\mathrm{mm}$ and $H$. pinifolia below $2 \mathrm{~mm}$. Moreover, both species showed different leaf tips forms. The $H$. uninervis are tridentate whereas the $H$. pinifolia are bifurcate. Furthermore, the leaf width measurements recorded from the sample fell on the range of wide leaf variety according to the ranges of measurements given by Den Hartog (1970), Lewmanomont et al. (1996), Sidik et al. (1999) (see Table 1) and none that fell on the narrow leaf variety. In this study, the arbitrary ranges of narrow and wide leaf were not clearly observed.

In the theoretical and conceptual framework of this study, it was assumed that there will be a difference of leaf width in relation to density (low and high) and sites (intertidal and subtidal). Therefore, it was expected that leaf width would be narrower in the intertidal and in high density; while it would be wider in the subtidal and low density. However, the results showed that leaf widths varied only between intertidal and subtidal but not between high and low densities beds. Leaf width is wider in subtidal area and is narrower in intertidal area.

Measured data indicated that the temperature structure was highly dynamic and directly linked to meteorological conditions. Water temperatures showed a strong correlation to external meteorological forces, changing at both daily and longer frequencies. The November-February data set corresponded to the typical cool dry season in the Philippines. For the time period of December 2010January 2011, shown in Figure 10 and 12, these were very cloudy and windy months, where light were minimal and additional local rainfall was maximal throughout those months. Thus the recorded temperatures were decreasing. After 
a year period of observation, the Hobo submerged loggers recorded that during the day, the water column temperature was higher and reaches a maximum stratification at $32.35{ }^{\circ} \mathrm{C}$ during the midday time. During the night; water column was cooled continuously and the temperature decreased to $27.17^{\circ} \mathrm{C}$ in the intertidal. Whereas the subtidal the highest temperature reached $30.32{ }^{\circ} \mathrm{C}$ and the lowest $26.68{ }^{\circ} \mathrm{C}$ respectively. According to McKenzie 1994; McKenzie and Campbell 2004, these are still within the range of fluctuations in seasonal seawater temperatures in tropical habitats $\left(19.8\right.$ to $\left.41^{\circ} \mathrm{C}\right)$.

Incident light intensity varied in connection with the period of high sun and the degree of cloudiness. Average light intensity measurements in situ for both intertidal and subtidal areas in Bantayan Beach were an order of magnitude whereas the light intensities annual values in intertidal reached as high as 44000 Lux in intertidal and 23000 Lux in subtidal areas. Compare to other studies, the light intensity data for both intertidal and subtidal areas were about 2 to 4 times greater than photosynthetic light intensity saturation values for eelgrass Zostera marina around 12000 Lux where this species also had the experience of light irradiance values around 30000 Lux (Rountos 2008). Moreover, Zavodnik et al. (1998) found that the annual average light intensity fluctuated between 19000 Lux - 32000 Lux around the seagrass bed of Cymodocea nodosa in Farbosa Bay.

Although variable morphology may reflect the differences in growth dynamics of different sites, it is also assumed that any one of several environmental aspects could be driving morphological alteration. The present-day distributions and abundances that lead to growth and survival of different species of seagrass reflect their specific requirements for the critical factors such as temperature, light, dissolved carbon dioxide, nutrients and a suitable substrate for anchoring (Green and Short 2003 and Waycott et al. 2007). The significant diversity of morphologies in genus Halodule characterized by a large variation in leaf width among collection sites occurring in Central Visayas indicated the plastic phenotype of Halodule could be connected to the dynamic fluctuation of environmental conditions. Previous studies by McMillan 1978; Phillips and Lewis 1983; Japar et al. 1999; Japar et al. 2008 and Hedge et al. 2009 verified the effects of some environmental factors on morphology, physiology, and survival in various Halodule species. 


\section{CONCLUSIONS}

The present study documented the variability of the leaf width of H.uninervis and $H$. pinifolia performed at three sites with different morphological adaptation to different environmental conditions. Leaf width of $H$. uninervis falls in the range of 2.7 to $4.0 \mathrm{~mm}$ and $H$. pinifolia was in the range of 0.8 to $1.8 \mathrm{~mm}$. Leaf width of $H$. uninervis was found much wider in the subtidal relative to the intertidal areas. However, this variability loosely follows the trends that had been observed by other researchers since there was no arbitrary range for wide and narrow leaf of $H$. uninervis that was observed in this study. Variations of temperature and light intensity were both observed annually; and showed clear pattern of seasonal change both in the intertidal and subtidal areas. Moreover, the variation result of the leaf width obtained reflect also the dynamic environment of each sites, thus a further investigation is required in multivariate relationship among nutrients availability in the water column and in the sediment, temperature, and light to fully suit the morphological changes in seagrasses in the Central Visayas, Philippines.

\section{LITERATURE CITED}

Beer, $S$ and Y.Waisel,

1982 Effects of light and pressure on photosynthesis in two seagrasses. Aquatic Botany 13: 331-337.

Dawson, S.P. and W.C. Dennison.

1996 Effects of ultraviolry and photosynthetically active radiation of five seagrass species. Marine Biology 125:629-638.

den Hartog, C.

1970 The Seagrasses of the World. North Holland Publishing, Amsterdam. 275 pp.

den Hartog, C. and J. Kuo

2006 Taxonomy and biogeography of seagrass. In: A.W.D. Larkum, R.J.Orth and C.M. Duarte (eds.). Seagrass Biology, Ecology and Conservation. Springer. Nederlands: 1-23. 
Dennison, W.C.

1987 Effects of light on seagrass photosynthesis, growth and depth distribution. Aquatic Botany 27:15-26

Durako, M.J. and M.D. Moffler.

1985 Observations on the reproductive ecology of Thalassia testudinum (Hydrocharitaceae). II. Leaf width as a secondary sex character. Aquatic Botany 21:265-275.

Fortes, M.D.

1986 Taxonomy and Ecology of Philippines Seagrass. PhD Disertation. College of Science, University of The Philippines, Diliman Quezon City. 245 pp. plus appendices.

Green, E.P. and F.T. Short.

2003 World Atlas of Seagrasses. Prepared by the UNEP World Conservation Monitoring Centre. University of California Press. Berkeley, USA. 298 pp.

Hedge, S., Smith, N. and R.K.F. Unsworth.

2009 Temporal and spatial morphological variability of the seagrasses Halophila ovalis and Halodule uninervis throughout the Great Barrier Reef region: Preliminary analysis. Report to the Marine and Tropical Sciences Research Facility. Reef and Rainforest Research Centre Limited, Cairns .15 pp.

Hellblom, F. and M. Björk.

1999 Photosynthetic responses in Zostera marina to decreasing salinity, inorganic carbon content and osmolality. Aquatic Botany, 65:97-104.

Herbert, D.A.

1986 Staminate flowers of Halophila hawaiina: Description and notes on its flowering ecology. Aquatic Botany 25: 97-102.

Jacobs, R.P.W.M. and E.S. Pierson.

1981 Phenology of reproductive shoots of eelgrass, Zostera marina L. at Roscoff (France). Aquatic Botany 10: 45-60. 
Japar Sidik, B., Z.M. Harah, A.M. Pauzi and S. Madhavan.

1999 Halodule Species from Malaysia - Distribution and Morphological Variation. Aquatic Botany 65:33-45.

Japar Sidik, B., N.A. Nazri, Z. M. Harah, A. Arshad and H. Ogawa.

2008 Morphology Plasticity of Halodule Species in Response to Different Environment. Marine Research Indonesia 33 (1): 11-16.

Johnstone, I.M.

1978 The Ecology and distribution of Papua New Guinea Seagrasses: 1. Additions to the Seagrass Flora of Papua New Guinea. Aquatic Botany 5: 229-233.

Keller, M. and S.W. Harris.

1966 The Growth of eelgrass in relation to tidal depth. Journal of Wildlife Management 30: 280 - 5.

Kuo, J. and C. den Hartog,

2001 Seagrass taxonomy and identification key. In: Short, F.T. \& R.G. Coles (Eds.). Global Seagrass Research Methods. Elsevier, Amsterdam:. 3158.

Lewmanomont K., S. Deetae, and V. Srimonobhas.

1996 Seagrass in Thailand. In: J. Kuo, C. Phillips, D.I. Walker and H. Kirkman (eds.). Seagrass Biology. Proceeding of an International Workshop, Rottnest Island, Western Australia: 21-26.

Longstaff, B.J. and W.C. Dennison.

1999 Seagrass survival during pulsed turbidity events: the effects of light deprivation on the seagrasses Halodule pinifolia and Halophila ovalis. Aquatic Botany 65: 105-121

Lopez-M, A.E and S.E. Ibarra-Obando.

1999 Annual life cycles of two Zostera marina L. populations in the in the Gulf of California: contrasts in seasonality and reproductive botany. Aquatic Botany 65: 59-69 
Meñez, E.G, R.C Phillips and H.P Calumpong.

1983 Seagrasses from the Philippines. Smithsonian Contribution to the Marine Science: 21. 40.

Meñez, E. and H. P. Calumpong.

1985 Halophila decipiens: An unreported Seagrass from the Philippines. Proceedings Biology Society Washington 98: 232-236.

McKenzie, L.J.,

1994 Seasonal changes in biomass and shoot characteristics of a Zostera capricorni Aschers. dominant meadow in Cairns Harbour, Northern Queensland. Australian Journal and Marine. Freshwater Research 45, $1337-1352$.

McKenzie, L.J. and S.J. Campbell.

2004 Surviving The Summer Heat: Seagrass Burns As Corals Bleach!!!, Seagrass-Watch News 19, p. 1.

McMillan, C.

1978 Morphological diversity under controlled conditions for the Halophila ovalis- $H$. minor complex and the Halodule uninervis complex from Shark Bay, Western Australia. Aquatic Botany 17: 29-42.

McMillan, C.

1979 Differentiation in response to chilling temperatures among populations of three marine spermatophytes, Thalassia testudinum,Syringodium filiforme, and Halodule wrightii. American Journal of Botany 66:810819.

McMillan, C.

1980a Reproductive physiology in the Seagrass, Syringodium filiforme from the Gulf of Mexico and the Caribbean. American Journal of Botany 67 (1):104-110. 
McMillan, C.

1980b Staminate flowers under controlled conditions by Cymodocea serrulata from Kenya. Aquatic Botany 9: 291-295.

McMillan, C.

1980c Flowering under controlled conditions by Cymodocea serrulata, Halophila stipulacea, Syringodium iseotifolium, Zostera capensis and Thalassia hemprichii from Kenya. Aquatic Botany 8: 323-336.

Mcmillan, C., B. Kent, R. Logan Kock and M. Falanruw.

1982 Fruit and seedlings of Cymodocea rotundata in Yap, Micronesia. Aquatic Botany, 14: 99-105.

McMillan, C.

1983 Morphological diversity under controlled conditions for the Halophila ovalis - H. minor complex and the Halodule uninervis complex from Shark Bay, Western Australia. Aquatic Botany 17: 29-42.

Phillips, R.C.

1967 On species of seagrass, Halodule, in Florida. Bulletin of Marine Science 17: 672-676.

Phillips, R.C. and T.W. Backman.

1983 Phenology and reproductive biology of eelgrass (Zostera marine L.) at Bahia Kino, Sea of Cortez, Mexico. Aquatic Botany 1: 85-90.

Phillips, R.C, and R.R. Lewis III

1983 Influence of environmental gradients on variations in leaf widths and transplant success in North American seagrasses. Marine Technology Society Journal 17:59-68.

Phillips, R.C., C. McMillan and K.W. Bridges.

1983 Phenology of eelgrass, Zostera marina L., along latitudinal gradients in north America. Aquatic Botany 15 (2): 145-156. 
Phillips, R.C. and E.G. Meñez.

1988 Seagrasses. Smithsonian Contributions to the Marine Sciences (34). Smithsonian Institution Press, Washington D.C. 104 pp.

Pirc, $\mathrm{H}$.

1986 Seasonal aspects of photosynthesis in Posidonia oceanica: influencence of depth, temperature and light intensity. Aquatic Botany 26. 203-212

Rasband, W.S.

1997-2011 ImageJ, U.S. National Institutes of Health, Bethesda, Maryland, USA. Retrieved from http://imagej.nih.gov/ij/

Ralph, P.J.

1999 Photosynthetic response of Halophila ovalis Hook.f to combined environmental stress. Aquatic Botany 1329: 1-4.

Rountos, K.,

2008 The role of porewater sulfide toxicity among other multiple stressors in Zostera marina populations in Long Island South Shore Estuaries. M.Sc. Thesis. Stony Brook University. 93 pp

Sauvageau, C.

1891 Sur les feuilles de quelques monocotyltdones aquatiques. Annales des Sciences Naturelles, VI1. Série Botanique 13:280-292.

Short, F.T., and R.G. Coles (eds.),

2001 Global Seagrass Research Method. Elsevier Science B.V., Amsterdam. 473 pp.

Silberhorn, G.M., R.J Orth and K.A. More.

1983 Anthesis and seed production in eelgrass from the Chesapeake Bay. Aquatic Botany 15: 133-144

Sidik, J.B., Z.M. Harah, A.M. Pauzi and S. Madhavan.

1999 Halodule species from Malaysia - distribution and morphological variation. Aquatic Botany 65:33-45. 
Sidik, J.B., N.A. Nazri, Z. M. Harah, A. Arshad and H. Ogawa.

2008 Morphology plasticity of Halodule species in response to different environments. Marine Research Indonesia 33 (1): 11-16.

Tomasko, D. A. and C. J. Dawes, M. D. Fortes, D. B. Largo and M. N. R. Alava 1993 Observations on a multi-species seagrass meadow offshore of Negros Oriental, Republic of the Philippines. Botanica Marina 36: 303-311.

van Tussenbroek, B.I.

1994 Aspects of reproductive ecology of Thalassia testudinum in Puerto Morelos Reef Lagoon,Mexico. Botanica Marina 37:413-419.

Vermaat, J.E, N.A Agawin, M.D. Fortes, J.S. Uri, C.M. Duarte, N. Marba, S. Enriquez and W. van Vierssen.

1997 The Capacity of seagrasses to survive increased turbidity and siltation: The significance of growth form and light use. Ambio 26 (1) 499-504

Waycott, M., K. McMahon, J. Mellors, A. Calladine and D. Kleine.

2004 A Guide to Tropical Seagrass of the Indo-West Pacific. James Cook University, Townsville. 72 pp.

Waycott, M., C. Collier, K. McMahon, P. Ralph, L. McKenzie, J. Udy and A. Grech.

2007 Vulnerability of seagrasses in the GBR to climate change (Chapter 8). In: Johnson, J. E. \& P. A. Marshall. (Eds.). Climate change and the Great Barrier Reef: a Vulnerability Assessment. Townsville, Australia, Great Barrier Reef Marine Park Authority and Australian Greenhouse Office.

Zakaria, M.H., B.J. Sidik and O. Hishamuddin.

1999 Flowering, fruiting and seedling of Halophila beccarrii Aschers from Malaysia. Aquatic Botany 65: 199-207.

Zavodnik, N., A Travizi, and S. de Rosa.

1998 Seasonal variations in the rate of photosynthetic activity and chemical composition of the seagrass Cymodocea nodosa (Ucr.) Asch. Scientia Marina 62 (4): 301-309. 